\title{
Which Research Paradigm for TESOL?
}

\author{
Mark Brooke \\ The Hong Kong Institute of Education, Hong Kong SAR, China
}

\begin{abstract}
This paper argues for action research methodology in educational research settings, in this case, the field of adult university education for TESOL (Teaching English to Speakers of Other Languages). A brief comparison of positivism and interpretivism is given to anchor action research within the interpretivist paradigm. Then follows an exploration of why action research as a research approach is meaningful for TESOL, focusing particularly on how it commits to solving educational problems through participatory, small-scale community projects. This, it is believed, gives a voice to all participants involved, not only the researcher. It also enables researchers to continually reflect on their practices, facilitating change and, it is hoped, professional development, which is an important goal of action research. To conclude, it is argued that research in the field of TESOL still predominantly equates itself with abstract linguistic theory, withdrawn from the reality in which teachers and learners live. Using Habermasian theory, this paper concludes that the positivist approach to educational research is still predominant in TESOL and that this might be explained as a reflection of a System perpetuating its hegemony over a Lifeworld, which is struggling for a voice to express its humanitarian values.
\end{abstract}

Index Terms-qualitative research, ontology, epistemology, positivism, interpretivism, action research, system, lifeworld

\section{INTRODUCTION - OPPOSING PARADIGMS IN EDUCATIONAL SOCIAL RESEARCH}

Traditionally, researchers have viewed educational research as made up of juxtaposed paradigms or 'sets of beliefs that guide action' (Guba, 1990, p.17). These research traditions and methods can be broadly described as those pertaining to a scientific model or positivist approach preferring quantitative research methodology and those of the naturalistic or interpretative approach, which predominantly apply qualitative techniques for study. As Nunan remarks:

'One reason for the persistence of the distinction between quantitative and qualitative research is that the two approaches represent different ways of thinking and understanding the world around us. Underlying the development of different research traditions and methods is a debate on the nature of knowledge and the status of assertions about the world, and the debate itself is ultimately a philosophical one'. (1992, p.10)

The different ways of thinking and understanding the world that guide researchers' actions are reflected in their ontological and epistemological standpoints.

\section{ONTOLOGY AND EPISTEMOLOGY}

Ontology and epistemology are distinguished in numerous ways dependant on the research paradigm that defines them. Ontology questions the nature of being or existence. Perception is a cognitive process which transfers information from the world to the brain. However, the question concerns the role of experience with regard to perception. Is there a true, external reality independent of mind or is it internalized and shaped by the observer's interpretation of what he perceives? If yes, to what extent? Is, as proponents of hermeneutics (the art or science of interpretation) claim, the idea of objective truth an illusion (see Heywoods and Stronach, 2005)? The metaphysical subjectivists state that it is in fact perception that is the sole creator of reality. Epistemology refers to the nature of knowledge itself and the relationship between the inquirer and the known. This puts under scrutiny questions pertaining to whether knowledge is a set of value-free truths, transcending opinion, or whether it is subjectively built and progressively understood, through experience. Epistemology asks: what is knowledge? How is it acquired? And what do people know? The abilities to describe what something is, why something exists and how something works represent some of the different forms of knowledge.

\section{Positivism: Its BeLIEFS, ORIGINS AND PRACTICES}

Positivism, in varying degrees proposes critical realist ontology: the belief that the world exists, external to and irrespective of, human perception. This belief is also known as epiphenomenalism. Experience is considered as an incidental by-product of information processing. An objectivist epistemology is emphasised: world facts and data (the known or to-be-known) are to be discovered and transferred to beings in the world. This is a nomothetic or etic science from an outsider perspective, (Watson-Gegeo, 1988), centering on probabilities through the collection of (commonly) large scale, quantifiable data in an objective and controlled way. Methods used in positivist research include experiments, questionnaires; Likert scaling; and structural equation modeling. Internal and external validity are essential components of quantitative research. Generally speaking, findings can be internally invalid if these have been 
influenced by factors other than those reported. They may be externally invalid if these are inapplicable to contexts other than the one where the research was conducted.

The positivist paradigm has been prominent historically in the social sciences. Hitchcock and Hughes (1995) note that this dominance began in the late nineteenth century. According to Vidich \& Lyman (2003), a significant number of ethnographer-researchers in the field would use checklists of traits with which to categorize a given society's evolution. This provided ethnographic and anthropological expeditions with a group of a-priori beliefs regarding the 'other': a being deemed to connect us to our ancestors. The term given to this by Lovejoy (1936) was the 'chain of being' (Vidich \& Lyman (2003, p.64). Through studying 'primitive', indigenous communities (i.e. the American Indians), researchers claimed that there was a 'spatio-temporal hierarchy of values' (Ibid: 64) to help them foresee the evolutionary states these societies would pass into. Following Comte (1798-1857), this diachronic study of societies was usually categorized as having 3 stages: savagery, barbarism and civilization. Vidich \& Lyman (2003, p.71) argue that the study of Native Americans is still a part of the cultural anthropology of 'primitive' peoples, whereas those of Europeans, Asians and American Blacks are institutionalized features of Sociology courses on "minorities" and "race and ethnic relations". Later on even into the 1960s and 70s many quantitative researchers realised that they had corroborated:

'[...] with imperial governments in the suppression and exploitation of natives, or with the American military and its 'pacification' programmes in Vietnam' (Vidich \& Lyman (2003, p. 66).

In its early days, this paradigm therefore revealed to what extent a human being could become a fact. Consequently, it could be claimed that theirs was not a respectful view of humans and the societies in which they exist (see Gupta \& Ferguson, cited in Angrosino \& Mays de Perez, 2003, p.108).

\section{INTERPRETIVISM: ITS BELIEFS, ORIGINS, AND PRACTICES}

The interpretive paradigms within the social sciences stand in juxtaposition to the positivist approach. The origins of Interpretivism are often linked to critical thinkers such as Marx (1818-1883), Nietzsche (1844-1900), Simmel (18581918), Weber (1864-1920), Scheler (1874-1928), and Mannheim (1893-1947). Later on, interpretivism became more important as it grew in different disciplines: phenomenology/sociology (Schultz, Cicourel and Garfinkel; the Chicago School of Sociology); and anthropology (Boas ((1858-1942)) and Malinowski ((1884-1942)). Weber (1864-1920) argued that in human sciences it is necessary to have 'Verstehen' or understanding rather than mere 'Erklaren' or explanation; put another way, it is essential to be concerned with process (the why and the how) as well as outcome or facts (the where, the what, the who, and the when).

Researchers within the interpretivist paradigm rely on emic science (an insider perspective) and small-scale, specific projects such as case studies. A relative ontology is proposed. Thus, there are many differing realities in the world and thus research needs to take into account how human situations, behaviours and experiences construct realities which are inherently subjective. Indeed, qualitative research (Somekh \& Lewin, 2000) even promotes the reality of subjective experience:

'Reality [...] is something we construct with our minds as a product of our theorising. Theorising shapes reality, rather than the other way around'. (Walker and Evers, 1998, p.28)

Consequently, researchers are free to critique each other's work as an interpretation rather than a truth. Human behaviour is a complex interplay of socio-psychological factors. Interpretivists state that these do not lend themselves to value-free rationality and observation reduced to 'variables along the lines of the natural sciences' (Somekh, 2006, p.16) Thus, qualitative research attempts to represent a 'slice of life' (Hammersley \& Atkinson, 1995, p.10) through situated activity offering descriptions and interpretations of social contexts in order to gain a deep understanding of human opinion and behaviour.

To do this, the research is necessarily multi-methodological or 'triangulated'. Interpretations of 'triangulation' vary in educational research. Silverman states that it is:

'Comparing different kinds of data and different methods to see whether they corroborate one another' (2001, p.156).

Elliott \& Adelman define it as

'Gathering accounts of a teaching situation from three quite different points of view; namely those of the teacher, his pupils, and a participant observer' (1976, p.74).

Consequently, not one account, method of data collection or form of publication is adhered to per se. Researchers apply the right methodology to fully develop the point of the study. A researcher's experiences in the field may be conveyed through various forms: case study; an ethnographic-based performance art (Bagley: 2008); travelogues (LeviStrauss, 1966); documentaries that read like fiction (Mailer, 1957); even dances (see Bagley \& Cancienne, 2002). Whatever the defining principle (excluding the 'reverse engineered hypothesis' of 'grounded theory' during which the researcher only begins to have a focus after he has collected significant data), the process first involves the gathering of data with a particular research focus in mind.

Burns $(1999,2010)$ divides data-gathering methodology used for qualitative research into two categories. The first is 'observational techniques', which take place in the 'natural' loci (Angrosino and Mays de Perez, 2003, p.107): notes describing events; journals; recordings; transcripts of spoken interaction; diagrams i.e., seating plans. The second, nonobservational techniques: interviews and discussions; questionnaires and surveys; biographical accounts; documents (i.e., student work, classroom materials). When data is being collected, as Coffey \& Atkinson (1996) note, a system of 
categorizing or coding data into 'chunks', connected by data type or by the 'identification of key themes and patterns' (ibid: 26), offers an initial analysis. This chunking is the 'code-and-retrieve' process. This is commonly done using a word or phrase to amalgamate data segments which inform the research objectives. Once coding is accomplished, analysis often consists of: summarizing the predominance of codes, presenting similarities and differences in related codes or comparing one or more codes. Analysis may then lead to further data gathering and investigations to 'generate meaning' (ibid: 46).

Because of the rich variety of data collection methods, Richardson likens qualitative research to crystallization. Research projects grow and change as crystals do but each part is interwoven in an ever-increasingly complex but fundamentally related pattern. Thus the researcher is often surmised as a 'quilt maker', patching data forms together to form a whole, or a 'bricoleur':

'A jack of all trades, or a kind of professional do-it-yourself person'. (Levi-Strauss, 1966, cited in Denzin \& Lincoln, 2003, p.17)

These practices seek to transform the world. As a result, interpretivists have been labelled by positivists as social critics, rather than scientists. Indeed, as Ledwith (2007) proposes that 'staying critical' is essential. Critical practice, she posits, is regarded as any that has a transformative social justice intention. Research needs to be emancipatory. This may happen in a range of contexts, from grassroots community activism to more institutionalised settings, such as hospitals, schools or universities. According to Flick (in Denzin and Lincoln, 2003) to do this, there is a need for knowledge and practice to be studied as 'local knowledge and practice':

'The search for grand narratives is being replaced by more local, small-scale theories fitted to specific problems and particular situations' (cited in Denzin and Lincoln, 2003, p.14-15).

Research participants are not data but human voices deeply connected with and concerned about the topic of investigation. This stems, to a large extent, from the belief that Christians expounds:

'All humans are worthy of dignity and sacred status, without exception for class and ethnicity' (cited in Denzin and Lincoln, 2003, p.129).

There is value in each individual's beliefs and research should strive to portray them. As Lacey states, his social anthropological fieldwork in a grammar school in the UK required:

'Sympathy, naivety, openness, a willingness to help where possible, and an ability to let people talk' (1976, p.116).

\section{ACTION RESEARCH IN TESOL}

Action research (AR) is an important approach within the interpretivist paradigm. It is particularly effective in TESOL (Teaching English to Speakers of Other Languages) settings because, as Edge (2001) argues, TESOL reflects an underpinning belief in and respect for the diversity of individuals and their learning processes. It thus encourages cooperative inquiry and inherently lends itself to notions of community. In addition, AR is conducted more generally in localized teaching situations and it strives to give a voice to all participants through its findings. In addition, as it tends to have a wider view on SLC dynamics, being interested in every element for change it is more able to describe the complex nature of SLCs (Ahmadian, \& Tavakoli, 2011).

Burns $(1999,2010)$ notes that a diverse set of researchers may be involved in AR in educational settings: universityresearchers or teacher-researchers working alone; groups of teachers working with university researchers; teacherresearchers working together; teachers with administrators, students, parents or other community members. This particular paper is more concerned with the teacher as teacher researcher. Allwright (1993), Allwright \& Bailey (1991); Burns (1999, 2010); Edge (2001); Elliot (1991); Freire (1970); Nunan (1993) are amongst those who are established action researchers. Others are more known for related models, such as 'collaborative action research' (Kuhlmann, 1992; Matsumoto, 1996; Wolf, 1996) and 'participatory action research' (Kemmis \& McTaggart, 1988).

The AR approach provides an essential structure to direct processes of practical situated research combined with focused reading or deliberative reflection in the field under study. Aristotle states in his Nicomachean Ethics (Book 2, chapter 1, p.1):

'For the things we have to learn before we can do them, we learn by doing them.'

In reality, it is only through experiential learning and task repetition that it is truly possible to become a more effective practitioner. With regard to experiential learning, it is possible to read accounts from other research but each context is unique and variables characteristic of that context renders any account of previous research particular. In addition, once a research project is underway, repeating interventions to improve or merely to confirm their worth is essential in order to change or fine tune strategies used to obtain the research goals.

The first step in any AR project is to notice and then take responsibility for a problem. This then leads to a process of trial and error investigation. Angrosino and Mayes de Perez (cited in Denzin and Lincoln, 2003, p.112) have labelled this process ethnography's 'self-correcting investigative process'. It is a process of exploratory change with spiral of planning, action, observation, and reflection. This is then followed by further-planning and so round the spiral once more. In AR projects, changes in some elements automatically affect other aspects of the context, and these may also demand responses. Even if the teacher finds it very difficult to make satisfactory improvements in aspects of his work, it is believed that the observations and subsequent responses lead to the teacher's deeper understanding of his context and personal methodology. This typically invites further questioning and reading. 
Quantitative research is critical of approaches within the interpretivist paradigm because it is said that these do not seek to prove the validity of their findings. Up to a point this may be true because action research does not posit that it holds assumptions regarding the value-free nature of its results. However, despite this, it is still faced with questions about the credibility of its investigations. Anderson et al (1999, pp. 161-162) outline five criteria: democratic validity, which questions whether the research has been truly collaborative, inclusive and multi-voiced; outcome validity, which refers to actions leading to successful outcomes. This not only questions whether the resolution to a problem has been found but also whether any reframing of the problem has taken place leading to further questions and exploration; process validity, which raises questions regarding the dependability of the research, in particular to what extent different sources and perspectives are voiced to avoid over-simplifications in interpretation; catalytic validity, which discusses whether the project has allowed participants to deepen their understanding of the social realities of the context. For example, have teachers and learners noticed changes in their roles or perceptions since the research was begun and if so, how? Finally, dialogic validity asks whether a project has been through any peer reviewing processes i.e., academic journals, dialogues with practioner-peers or other critical friends. In sum, validity plays an important role in action research. By analyzing these constructs of validity, a research project is deeply-rooted in honouring the status of all stakeholders involved, as well as making the research socially relevant and explorative.

\section{The FutURE OF ACTION RESEARCH IN TESOL}

Despite the arguments for action research above, there has been, and still is, a visible gap in TESOL between applied linguistics and the pedagogy of the second language classroom (SLC) with theoretical papers more prominent than case studies based on situated learning. Comments explicating this concept can be traced back over the last 20 years. In 1993 , Somekh noted that the more abstract the research, the higher the academic standing; the more practical, the lower the standing. In 1992, Van Lier posited that theory and practice were not:

'... perceived as integral parts of a teacher's practical, professional life'. This situation is the result of communication gaps caused by an increasingly opaque research technocracy, restrictive practices in educational institutions and bureaucracies (e.g. not validating research time, or not granting sabbaticals to teachers for professional renovation), and overburdening teachers who cannot conceive of ways of theorizing and researching that come out of daily work and facilitate that daily work. (1992, p.3)

Ten years on Greenwood \& Levin (cited in Denzin and Lincoln, 2003, p.142) referred to educational research as 'armchair activity' and Somekh and Lewin (2005, p.8), argued that policymakers were under ever-increasing pressure to justify spending on education. The argument was that the academic freedom researchers strove for was lost as research budgets were primarily offered to those who can supply hard data. Thus socially relevant research was marginalised. This was more recently vilified in a publication by Clayton; O'Brien; Burton; Campbell; Qualter; and Varga-Atkins (2008), who found that there is still a preference in educational establishments (i.e., schools and universities in the UK) for the positivist culture of numerical targeting. These methods, predominantly aspire to proving cause and effect between educational practice and assessment scores. Today, there still remains a 'hierarchy of credibility' (Altrichter, Posch \& Somekh; 1993, p.202), which distrusts practitioners. As López-Pastor, Monjas \& Manrique (2011, p. 154) argue, the theory-practice separation in educational research and in educational management can be extremely detrimental for teachers and students alike as it leads to the delivery of

'School proposals that are made by people who are not completely aware of school teaching practice.'

In addition, it is only fairly recently that educational AR has appeared to be predominantly the work of a lone ranger or isolated individual. AR, at its origins with Dewey (1933) and Lewin (1946) and later with Schon (1983), McTaggart (1989), Burns (1999, 2010) and Edge (2001), has most often been associated with collaboration. Dewey's (ibid) ideas were essentially democratic, based on the idea that researchers, practitioners and others involved in the educational community should address their efforts towards educational inquiry collectively: a single teacher narrows the opportunities for research and reduces its power.

\section{ACTION RESEARCH AND THE LIFEWORLD’s STRUGGLE}

Habermas (2000) explicates that the System, led by the institutions of power and wealth that exist in the world: multinational corporations; the military; the administration (including education), consciously rejects the ideals of community. In contrast, the values and ideals of the Lifeworld are built collaboratively through interpersonal relations and 'communicative action'. The Lifeworld is concerned about:

'Clean air; fresh water; biodiversity; unadulterated food; health care; education; child/elder care and productive work'. (Habermas cited in Sumner, 2000, p.269)

The System must undermine the community to maintain itself. If it does not, hegemony might be endangered. 'Common language' and 'communicative action' not only refer to a lingua franca but also to other concepts foreign to the System, such as 'diversity', 'community', 'emancipation', 'voice', 'commitment' and 'support'. The more communication there is, the more 'noise' (cited in Nipper, 2000, p.276) there is, in the system. This 'noise' is the sound of people interacting, ultimately leading to: 
'Learning situations based on the search for solutions to real-life, open-ended problems'. (Greenwood \& Levin, 2003, p.133)

It might be claimed that the dominance of the positivist approach in social research aids the marginalizing and the silencing of the Lifeworld. If the System wishes to maintain control in educational settings, it is possible that using statistical probabilities to design research methodology and obtaining data randomly from disconnected people to create generalizations for numerical analysis, is one way of doing this. The System can then tell us what it believes we should know, justifying this fact on data which we cannot test nor relate to. Our own questioning and subsequent research appears insignificant when compared to the large-scale, substantial figures sought through scientific inquiry. Foucault (cited in Hamersley and Atkinson, 1995, p.14) argued that this kind of mass society representationalism functions as part of the System's surveillance and control in modern society. To sum up, it inherently leads to social disengagement and silences too many voices.

A focus on the local, the unique, the connectedness of all TESOL participants involved in a research project, and the commitment to do what seems to be right for oneself and significant others should be the essence of educational action research with its multi-voiced and multi-methodological approach. This is research in perpetual motion, one which may exhibit feminist perspectives for the SLC as easily as class or gender perspectives; one which should offer an interesting perspective on a particular topic or set of topics to other like-minded individuals, without trying to prove that it presents a universal truth. Evidently, the role of the researcher is to be ever-mindful of his own reflexivity as this must affect the data production and collection processes. However, reflexivity is not something to attempt to do away with. Rather, the researcher should strive to understand his own perspectives clearly; to be aware that this shapes his vision and guides his work; and to communicate how this interacts with the research account. This allows for complexity to be accepted openly and as far as research methods go, might lead to what Geertz referred to as 'blurred genres' (cited in Denzin and Lincoln, 2003, p.26), which openly accept all strategies of discovery. This need not mean a 'crisis of representation'. Rather, as Walker and Evers' (1998, p.30) 'complementary diversity thesis' argues, there is no monopoly on truths only complexity and change in the social world welcoming a:

'New age where messy, uncertain, multi-voiced texts, cultural criticism, and new experimental works will become more common, as will more reflexive forms of fieldwork, analysis and inter-textual representation'. (Denzin and Lincoln 2003, p.38)

\section{CONCLUSION}

As Seymour and Davies (2002) state, the interpretivist paradigm is for people not only about them. This paper has sought to make evident that, by its very nature; action research is well-suited as an approach in the TESOL environment. This is because, first, it is founded on humanitarian characteristics, second, it seeks more multi-voiced and multimethodological findings and third, it strives to find solutions to real life problems. In seeking these solutions, it tends to offer a slice of life to its readers. This paper has also sought to argue that research in this field is still dominated by abstract linguistic theory, withdrawn from the reality in which teachers and learners live. It has also been suggested, that it is possible to apply Habermasian theory to explain why this might be the case. This paper therefore concludes that there is a need for more action research conducted by teacher-researchers; and the development of this approach to better understand TESOL and its complexities.

\section{REFERENCES}

[1] Ahmadian, M., \& Tavakoli, M. (2011). Exploring the utility of action research to investigate second-language classrooms as complex systems. Educational Action Research, 19(2), 121-136. doi:10.1080/09650792.2011.569160.

[2] Allwright, D. \& Bailey, K. M. (1991). Focus on the Language Classroom, Cambridge: CUP. UK.

[3] Allwright, D. (1993). Integrating research and pedagogy: appropriate criteria and practical possibilities. In Edge, J. \& Richards, K. (1993). Teachers Develop Teachers Research. Oxford: Heinemann. UK.

[4] Altrichter \& Holly. (2005). Research diaries, in Somekh, B \& Lewin C (Eds.), Research Methods in the Social Sciences, Sage Publications, London. UK.

[5] Altrichter, H., Posch, P. \& Somekh, B. (1993). Teachers Investigate Their Work: an introduction to the methods of action research. London: Routledge. UK.

[6] Anderson et al. In Burns, A. (1999). Collaborative Action Research for Language Teachers; CUP. UK.

[7] Angrosino and Mays de Perez in Denzin, N. K. \& Lincoln, Y. S. (Eds.), (2003). Collecting and Interpreting Qualitative Materials. Thousand Oaks, CA: Sage. Pp.107-155.

[8] Aristotle. Nicomachean Ethics. Translated by W. D. Ross. Oxford, Clarendon Press. UK. 1908 Edition.

[9] Bagley, C. (2008). Educational ethnography as performance art: towards a sensuous feeling and knowing. Qualitative Research, Vol. 8, No. 1, pp. 53-72.

[10] Bagley, C. \& Cancienne, M. B. (2002). Dancing the Data. New York: Peter Lang Publishers.

[11] Blumer, H. (1969). In Hammersley, M. \& Atkinson, P. (1995). Ethnography- Principles in Practice. Routledge. London. UK.

[12] Burns, A. (1999). Collaborative Action Research for Language Teachers. CUP. UK.

[13] Burns, A. (2010). Doing action research in English language teaching: A guide for practitioners. N.Y: Routledge.

[14] Clayton, O'Brien, Burton, Campbell, Qualter \& Varga-Atkins. (2008). Educational Action Research Journal, volume 16, issue 1, March 2008, pp $73-84$. 
[15] Coffey, A. \& Atkinson, P. (1996). Making Sense of Qualitative Data. Complementary Research Strategies, London: Sage. UK.

[16] Comte, A. The Evolution of Culture and Society in Denzin, K \& Lincoln, Y. (2003). The Landscape of Qualitative Research Theories and Issues. Thousand Oaks, CA: Sage.

[17] Denzin, K. \& Lincoln, Y. S. (Eds.), (2003). The Landscape of Qualitative Research Theories and Issues. Thousand Oaks, CA: Sage.

[18] Denzin, K. \& Lincoln, Y. S. (Eds.), (2003). Collecting and Interpreting Qualitative Materials. Thousand Oaks, CA: Sage.

[19] Dewey, J. (1933). In Denzin, K. \& Lincoln, Y. S. (Eds.), (2003). The Landscape of Qualitative Research Theories and Issues. Thousand Oaks, CA: Sage.

[20] Edge, J. (2001). Action Research, case studies in TESOL Practice Series. Alexandria: TESOL.

[21] Elliott, J. (1991). Action Research for Educational Change. Milton Keynes: Open University Press. UK.

[22] Elliott, J. \& Adelman, C. (1976). Innovation at the Classroom Level: A Case Study of the Ford Teaching Project. Milton Keynes. Open University Press. UK.

[23] Flick, U. in Denzin, K. \& Lincoln, Y. S. (Eds.), (2003). The Landscape of Qualitative Research Theories and Issues. Thousand Oaks, CA: Sage.

[24] Freire, P. (1970). Pedagogy of the Oppressed, N.Y: Seabury.

[25] Greenwood \& Levin in Denzin, N. K. \& Lincoln, Y. S. (Eds.), (2003). The Landscape of Qualitative Research Theories and Issues. Thousand Oaks, CA: Sage. Pp131-166.

[26] Guba, C. E. (1990). The Alternative Paradigm Dialog. In E. G. Guba (Ed). The Paradigm Dialog (pp 17-30). Newbury Park, CA: Sage.

[27] Habermas, J. (1963). In Sumner, J. (2000). Serving the System: a critical history of distance education, Open Learning, Vol. 15, No. 3, pp. 267-285.

[28] Hammersley, M. \& Atkinson, P. (1995). Ethnography-Principles in Practice. N.Y. Routledge.

[29] Heywards, D. \& Stronach, I. (2005). Philosophy and hermeneutics, in Somekh, B \& Lewin C (eds.), Research Methods in the Social Sciences, Sage Publications, London.

[30] Hitchcock, G., \& Hughes, D. (1995). Research and the teacher: A qualitative introduction to school-based research (2nd Ed.). N.Y: Routledge.

[31] Kemmis, S. and McTaggart, R. (1988). The Action Research Planner (Eds), $3^{\text {rd }}$ Edition, Deakin University Press, Victoria, Australia.

[32] Kuhlmann, A. in Denzin, K. \& Lincoln, Y. S. (Eds.), (2003). Collecting and Interpreting Qualitative Materials. Thousand Oaks, CA: Sage.

[33] Lacey, C. (1976). Problems of Sociological Fieldwork: A review of the methodology of Hightown Grammar, in Hammersley, M (Ed). (1993). Educational Research Current Issues, London: Paul Chapman. Pp114-131.

[34] Ledwith, J. (2007). Educational Action Research, Volume 15, Issue 4, Dec, pp. 597-611.

[35] Levi-Strauss, C. (1966). The Savage Mind. Chicago. University of Chicago Press.

[36] Lewin, K. (1946). In Denzin, N. K. \& Lincoln, Y. S. (Eds.), (2003). Collecting and Interpreting Qualitative Materials. Thousand Oaks, CA: Sage.

[37] López-Pastor, V. M., Monjas, R., \& Manrique, J. (2011). Fifteen years of action research as professional development: seeking more collaborative, useful and democratic systems for teachers. Educational Action Research, 19(2), 153-170. doi:10.1080/09650792.2011.569190.

[38] Lovejoy (1960). In Denzin, N. K \& Lincoln, Y. S. (2003: 64) The Landscape of Qualitative Research Theories and Issues. Thousand Oaks, CA: Sage.

[39] Mailer. N. (1957). The White Negro. Article published in 'Dissent Magazine', N.Y.

[40] Matsumoto, V. In Denzin, K. \& Lincoln, Y. S. (Eds.), (2003). Collecting and Interpreting Qualitative Materials. Thousand Oaks, CA: Sage.

[41] Nipper. S. (1989). In Sumner, J. (2000). Serving the System: a critical history of distance education, Open Learning, Vol. 15, No. 3, pp. 267-285.

[42] Nunan, D. (1992). Research Methods in Language Learning, CUP: Cambridge. UK.

[43] Nunan, D. (1993). Action research in language education. In Edge, J. \& Richards, K. (1993). Teachers Develop Teachers Research. Oxford: Heinemann. UK.

[44] Schön, D.A. (1983). The reflective practitioner: How professionals think in action, Basic Books, USA, 1983.

[45] Seymour, F.W. and Davies, E. (2002). Using action research to facilitate change in child protection services. J. Community Psychol., 30: 585-590. doi: 10.1002/jcop.10019

[46] Silverman, D. (2001). Interpreting qualitative data. Sage Publications. London. UK.

[47] Somekh, B. (1993). Quality in educational research - the contribution of classroom teachers. In Edge, J. and Richards, K. 1993. Teachers Develop Teachers Research. Oxford: Heinemann. UK.

[48] Somekh, B. (2006). Action research: A methodology for change and development. Glasgow: Open University Press. UK.

[49] Somekh, B \& Lewin, C. (2005). Research Methods in the Social Sciences. SAGE Publications. London. UK.

[50] Sumner, J. (2000). Serving the System: a critical history of distance education, Open Learning, Vol. 15, No. 3, pp. $267-285$.

[51] Van Lier, L. (1992). The Classroom and the Language Learner: Ethnography and Second Language Classroom Research. London: Longman. UK.

[52] Vidich \& Lyman in Denzin, N. K. \& Lincoln, Y. S. (Eds.), (2003). The Landscape of Qualitative Research Theories and Issues. Thousand Oaks, CA: Sage.

[53] Walker, J. \& Evers, C. (1998). 'The epistemological unity of educational research' in J. P. Keeves (Ed.), Educational research methodology and measurement: an international handbook, Pergamon Press, Sydney, pp. 28-36.

[54] Watson-Gegeo, K. A. W. (1988). Ethnography in ESL: Defining the Essentials. TESOL Quarterly, Vol. 22 , No. 4 (Dec., 1988), pp. 575-592. 
[55] Wolf. D. L. In Denzin, K. \& Lincoln, Y. S. (Eds.), (2003). Collecting and Interpreting Qualitative Materials. Thousand Oaks, CA: Sage.

Mark Brooke, BA (hons); MA; Dip., FLE; Licentiate Dip., TESOL; M.Sc in TESP

Mark is working as a Senior Teaching Fellow at the Hong Kong Institute of Education. Before this, he worked at the English Language Centre of City University, Hong Kong. Mark has published on various research subjects related to TESOL such as asynchronous computer-mediated discourse; online language learning communities; pre-service language teacher training; and using corpora for discovery language learning. He is currently in his sixth year of doctoral studies in educational technology with Durham University, UK. 